\title{
APC Fly Ash Recycling: Development of a Granular Material from Laboratory to a Pilot Scale
}

\author{
R. del Valle-Zermeño ${ }^{1} \cdot$ J. Giro-Paloma ${ }^{1} \cdot$ J. Formosa $^{1} \cdot$ J. M. Chimenos ${ }^{1}$
}

\begin{abstract}
The aim of this article is to present the research carried out over a 10 year period to develop an environmentally safe method for recycling air pollution control (APC) residues. The initial studies aimed to formulate a mixture of weathered bottom ash (WBA), APC residues and Portland cement (PC) to be used as a sub-base in road constructions. Mechanical performance was subsequently enhanced by preparing a mortar prior to mixing it with WBA in order to obtain a granular material. After testing different formulations, the optimum mortar consisted of $50 \%$ APC residues and $50 \%$ PC. The evaluation was carried out based on the concentration release of the heavy metals and metalloids included in the Catalan legislation for revalorization of residues. After the applicability of the granular material was successfully demonstrated at laboratory scale from an environmental and mechanical point of view, a pilot scale plant was designed in order to assess its performance in a real scenario during 4 month. Thus, three roads were built: two containing $100 \%$ granular material and a third containing $100 \%$ WBA. The results showed that the immobilisation of all toxic species from APC residues is accomplished by the pozzolanic effect of the cement. The WBA, APC, and PC proportions show to be the most appropriate for compliance with regard to environmental and mechanics requirements.
\end{abstract}

Keywords MSWI bottom ash $\cdot$ APC residues - Field scale road $\cdot$ Mortar $\cdot$ Granular material $\cdot$ Leaching study

\section{Introduction}

Waste management is a pressing environmental, social and economic issue. Waste is increasingly recognised as a resource today. Waste incineration has grew progressively between 1995 and 2013, although not as much as recycling and composting. This management technique, which include energy recovery, increased overall by $27.4 \%$ between 2004 and 2012. Since 1995, the amount of municipal solid waste (MSW) incinerated in the EU-27 has risen by 29.4 million tonnes and it accounted for 61.6 million tons in 2013 [1]. MSW incineration (MSWI) has therefore become a valuable alternative in field of waste management.

In Catalonia (Spain), the amount of MSW that ends up in landfill has decreased sharply in the last 10 years with respect to the EU-average [2]. This region has focused on the recycling of both materials (glass, metal, paper and cardboard, plastics etc.) and bio-waste, as well as moderate use of mechanical biological treatment. Because Catalonia has introduced separate collection of recyclables materials and bio-waste, the region is expected to recycle $50 \%$ of its MSW by 2020. Catalonia has succeeded in increasing both material and bio-waste recycling to a total rate of $41 \%$ of its MSW, keeping its incineration rate constant and reducing landfill to $40 \%$.

Although MSWI allows reducing the mass and volume of municipal waste while generating energy through combustion, around $30 \%$ of the total content remains as bottom ash (BA) and air pollution control (APC) ash (22-25\% as BA and 3-4 \% as APC). BA may contain glass, ceramics, concrete, brick, rubble, sand, metal, stone, and fused clinker, among others. Due to this composition, is considered a nonhazardous residue that can be revalorized as a secondary aggregate in road sub-base, bulk filler in construction, or 
cement bound materials. However, for its proper reutilization, BA must be stabilised through weathering process in order to obtain weathered bottom ash (WBA) [3]. On the other hand, APC residues are a mixture of fly ash and the reagents used during the flue gas treatment (mainly lime). Unlike BA, they are classified as hazardous waste and are generally disposed of in landfill disposal after stabilization, usually with Portland cement $[4,5]$.

If the cost of disposing of such waste in hazardous wastes landfill is taken into account, the amount of APC residues produced in an incinerator plant and its price per tone is an important issue that could be effectively addressed by revalorization. However, a proper reutilization process must take into account the potential release of pollutants (mainly heavy metals and other anionic species such as sulphates and chlorides) as road leachates [8]. Among the main factors that affect their mobility, $\mathrm{pH}$, which exerts a strong influence, especially on highly soluble phases. According to the literature, the following factors should be taken into account in a real scenario [610]: (1) the difference in temperature between labora- tory and field conditions, (2) hydrology and climatic fac- tors, (3) $\mathrm{pH}$ and redox conditions, (4) time scale, (5) mass transport rate, (6) ageing of material by carbonation and oxidation, (7) water infiltration rate and mechanisms, (8) degree of water saturation, and (9) the heterogeneity of a real sub-base with strong edge effects.

The aim of this paper is to present the findings relating to the recycling of APC fly ash as a secondary building material carried out over nearly 10 years from laboratory experiments to pilot-scale application. The exhaustive assessment started with the formulation of several mixtures containing WBA/APC/Portland cement (WBA/APC/PC) in order to evaluate them from a mechanical and environmental point of view, at laboratory scale. The results led to a reassessment of the residue mixing procedure, and a mortar made with different proportions of APC/PC was crushed and mixed in order to develop a granular material. After being environmentally and mechanically assessed at laboratory scale, this granular material was tested at pilot scale as a sub-base material in road constructions. As discussed in further detail below, three roads containing the material under study were constructed and assessed from an environmental and mechanical point of view in order to propose a safe alternative for APC recycling.

\section{Materials and Methods}

Materials

The WBA and APC fly ash samples were collected from a MSWI facility located in Tarragona (Spain). The feed stream treated in this incineration plant is mainly composed of household rubbish, with minor input from commercial sources. Approximately 35,000 tonnes per year of BA and 3000 tons per year of APC residues are produced in the incineration plant and further treated in a conditioned/ revalorization process for the recovery of valuable metals. After being produced, BA is stock-piled in the open air for at least 3-months to ensure that heavy metals are stabilised by weathering and hence obtaining WBA. Thus, around $150 \mathrm{~kg}$ of WBA and $50 \mathrm{~kg}$ of APC residues were taken every year from 2005 to 2015 (the period during which all laboratory scale experiments were performed). Several representative sub-samples were taken regularly every year for chemical and physical characterization and the results presented here are the average values obtained. The materials used in all experiments carried out over the 10 year period can generally be grouped into three stages:

(1) WBA/APC/PC mixtures; (2) Formulation of an APC/ PC mortar; (3) Development of a granular material made with mortar and WBA. The following sections describe how these materials were obtained and later sections present the physicochemical characterization and experimental procedure carried out for each of them.

\section{WBA/APC/Portland Cement Mixtures}

Different mixtures of WBA/APC/PC were considered for preparing non-structural precast concrete, as shown in Table 1. A design of experiments (DoE) was carried out with Design Expert $^{\circledR}$ software, taking into account the production of both residues (WBA and APC) and conducting preliminary tests, as well as sustainability factors. As also indicated, formulations 14-19 included the use of an admixture ( $0.5 \mathrm{wt} \%$ of PC content) to improve the fluidity of the paste (MIRA 43 from Grace Construction Products). A CEM I 52.5R cement was selected for this study to ensure early age strength development. For all concrete mixtures, the consistency was fixed in the $5-8 \mathrm{~cm}$ range using the Abrams cone method [11], which resulted in different water-to-cement (W/PC) ratio. Thus, three cylindrical specimens (1509300 mm, diameter/height) were cast for each formulation. Once cast and compacted, the concrete specimens were stored in a climatic chamber for $24 \mathrm{~h}$ before being demoulded and left to cure $\left(20{ }^{\circ} \mathrm{C}\right.$, $95 \%$ relative humidity) for 28 days. The mechanical properties of each specimen were subsequently tested by measuring the maximum compressive strength.

\section{APC/Portland Cement Mortar}

After obtaining the maximum compressive strength values mentioned in "WBA/APC/Portland Cement Mixtures" section, a mortar was prepared with $\mathrm{APC}$ and $\mathrm{PC}$ and then 
Table 1 Mixture proportions of WBA/APC/Portland cement

\begin{tabular}{|c|c|c|c|}
\hline $\begin{array}{l}\text { Number of } \\
\text { formulation }\end{array}$ & WBA $(\%)$ & $\mathrm{APC}(\%)$ & $\mathrm{PC}(\%)$ \\
\hline 1 & 60 & 20 & 20 \\
\hline 2 & 64 & 16 & 20 \\
\hline 3 & 66 & 14 & 20 \\
\hline 4 & 69 & 11 & 20 \\
\hline 5 & 72 & 8 & 20 \\
\hline 6 & 76 & 4 & 20 \\
\hline 7 & 80 & 0 & 20 \\
\hline 8 & 75 & 15 & 10 \\
\hline 9 & 80 & 10 & 10 \\
\hline 10 & 85 & 5 & 10 \\
\hline 11 & 77 & 15 & 8 \\
\hline 12 & 82 & 10 & 8 \\
\hline 13 & 87 & 5 & 8 \\
\hline $14^{\mathrm{a}}$ & 75 & 15 & 10 \\
\hline $15^{\mathrm{a}}$ & 80 & 10 & 10 \\
\hline $16^{\mathrm{a}}$ & 85 & 5 & 10 \\
\hline $17^{\mathrm{a}}$ & 77 & 15 & 8 \\
\hline $18^{\mathrm{a}}$ & 82 & 10 & 8 \\
\hline $19^{\mathrm{a}}$ & 87 & 5 & 8 \\
\hline
\end{tabular}

All percentages in a weight basis

${ }^{a}$ Formulations with admixture $(0.5 \%$ of the cement content $)$

mixed with WBA. In doing so, the effect of pozzolanic encapsulation was enhanced and the quantity of fines from APC reduced. According to DoE software, several mortar formulations were prepared using different proportions of $\mathrm{APC}$ and PC, as summarised in Table 2. The waterPortland cement (W/PC) ratio was fixed at $0.8(\mathrm{wt} \%)$. A polymer-based aqueous solution called Mortar $R$ (Grace Construction Products) was added as a fluidiser (0.5 wt $\%$ of the PC content) to improve its workability. The admixture used for these mortar formulations was different to that used for WBA/APC/PC mixtures because MIRA 43 was withdrawn from sale. According to the supplier, however, the two admixtures are very similar.

\section{Granular Material (GM) for the Pilot-Scale Roads}

The optimum mortar mixture in terms of environmental performance was selected to prepare a granular material with WBA. Thus, the mortar material was crushed and mixed with $80 \%$ WBA to obtain a WBA/APC/PC composition of $80 / 10 / 10 \mathrm{wt} \%$. As detailed below, this material was subject to environmental evaluation at both laboratory and pilot scale. The quantity of granular material required for the pilot scale study was calculated based on the Proctor density of WBA $\left(1700 \mathrm{~kg} \mathrm{~m}^{-3}\right)$ and the dimensions of the pilot scale road. The mortar was produced using a cement
Table 2 APC residues and Portland cement proportions (APC/PC) used for formulating the mortar (M)

\begin{tabular}{lll}
\hline $\begin{array}{l}\text { Number of } \\
\text { formulation }\end{array}$ & APC $(\%)^{\mathrm{a}}$ & $\begin{array}{l}\text { Portland } \\
\text { cement }(\%)^{\mathrm{a}}\end{array}$ \\
\hline 1 & 70.00 & 30.00 \\
2 & 59.22 & 40.78 \\
3 & 47.76 & 52.24 \\
4 & 50.00 & 50.00 \\
5 & 65.00 & 35.00 \\
6 & 30.00 & 70.00 \\
7 & 70.00 & 30.00 \\
8 & 59.22 & 40.78 \\
9 & 30.00 & 70.00 \\
10 & 30.00 & 70.00 \\
11 & 40.00 & 60.00 \\
12 & 30.00 & 70.00 \\
13 & 70.00 & 30.00 \\
14 & 45.00 & 55.00 \\
15 & 30.00 & 70.00 \\
\hline
\end{tabular}

${ }^{\mathrm{a}}$ Weight basis

mixer with a total capacity of $7 \mathrm{~m}^{3}$. Again, the W/PC ratio was fixed at 0.8 , since this produced the desired consistency in the range of 5-8 cm (Abrams cone method) [11]. Fresh mortar was poured into two $1.591 .590 .5 \mathrm{~m}^{3}$ formworks and left to cure for 28 days. The hardened mortar was the removed from the formworks and crushed with a digger to obtain the crushed material shown in Fig. 1. The crushed mortar was then $0-30 \mathrm{~mm}$ sieved and mixed with WBA to obtain the desirable composition of granular material. The secondary granular material obtained was then physically and chemically characterized.

Methods

\section{Chemical Characterization}

The average chemical composition of the major and minor elements of the WBA, mortar, APC, and granular material was determined by X-ray fluorescence (XRF) using a Philips PW2400 X-ray sequential spectrophotometer. With respect to the crystalline phases, these were determined by X-ray diffraction (XRD) using a Bragg-Brentano Siemens D-500 powder diffractometer with CuKa radiation.

\section{Mechanical Properties}

The compressive strength for the WBA/APC/PC specimens ("WBA/APC/Portland Cement Mixtures" section) was determined in accordance with the standard EN 12390-3 (2009). The abrasion resistance of the selected mixtures 


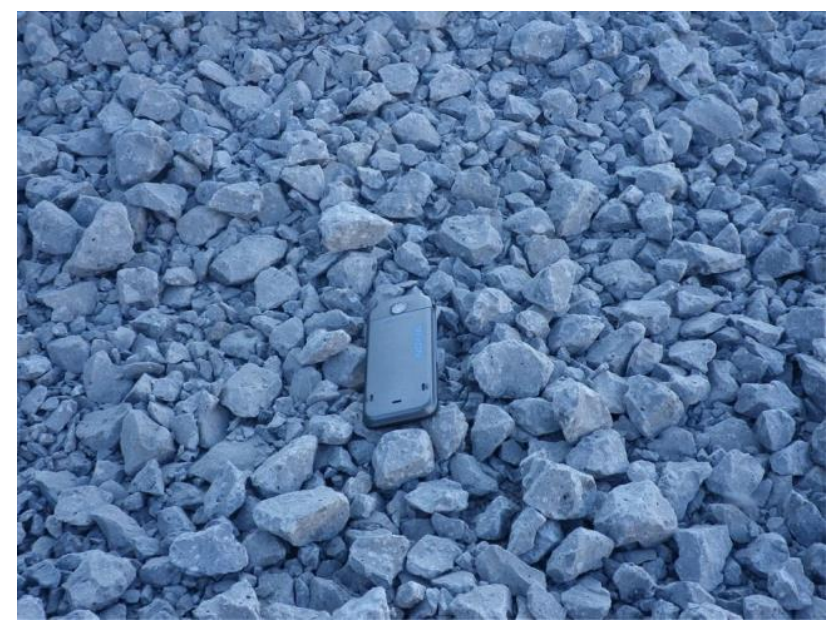

Fig. 1 Crushed hard mortar aspect before mixing with WBA for obtaining the granular material

was measured by means of the Los Angeles (LA) coefficient in accordance with the standard EN 1097-2 (1999). This coefficient measures the capacity of an aggregate material to maintain its physical integrity under defined abrasive conditions [12].

\section{Environmental Behaviour at Laboratory and Pilot-Scale}

The potential release of heavy metals and metalloids from the WBA/APC/PC mixtures, mortar, and granular material was evaluated at laboratory scale through one-step batch leaching test (EN 12457-4). The column-percolation test (CEN 14405) was subsequently applied to the granular material, in order to compare the results with those of the pilot-scale study. To ensure that a more accurate comparison could be carried out, some modifications were made to the column percolation standard test: (1) the size of the samples was not reduced; (2) a particular column ( $[=$ $150 \mathrm{~mm} ; \mathrm{h}=400 \mathrm{~mm}$ ) was used for all experimental trials; (3) demineralised water was used as a leachant and pumped from the bottom to fully saturate the column. The proper mass of the material to be packed in was calculated based on the thickness of the sub-base layer at the pilot road site, the column dimensions and the WBA optimal dry density and humidity (an average of $17.1 \%$ ) in the case of the granular material. A constant flow rate of 6 $\pm 0.5 \mathrm{~mL} \mathrm{~min}{ }^{-1}$ was chosen and different times $(10,20$, $30,45,60,120,360,480,1440,1560,1800$ and $2880 \mathrm{~min}$ ) were set for collection of eluate fractions. With respect to environmental performance during the pilot scale study, a leaching system was designed and used to collect samples at regular time intervals, as fully detailed in the section on the leachate collection system. The eluate fractions from both laboratory leaching tests and the samples obtained from the pilot-scale roads were analysed with respect to
$\mathrm{pH}$, conductivity and content of selected heavy metals, sulphates, and chlorides. Trace metals concentrations were determined by inductively coupled argon plasma mass spectrometry (ICP-MS) while spectrophotometry and a selective ion electrode (ISE) were used to determine the sulphate and chloride content, respectively.

\section{Pilot-Scale Plant}

Road Sites Description The pilot-scale plant consisted of three fully embedded roads in a $2 \mathrm{~m}$ high esplanade for easy water discharge by gravity. Each road measured approximately $39590.6 \mathrm{~m}^{3}$ and the structural cross section consisted of the following components from top to bottom: (1) a top layer (width $=200 \mathrm{~mm}$ ) formed by natural ballast measuring $\backslash 40 \mathrm{~mm}$, (2) a sub-base composed of the granular material (width $=200 \mathrm{~mm}$ ), (3) a layer of drainage grave measuring $\backslash 10 \mathrm{~mm}$ to cover a PVC pipeline for the leachate collection system (LCS), and (4) a waterproof layer formed by a geotextile membrane as a base liner. The three road unit were separated $1 \mathrm{~m}$ from each other and the base slightly sloped towards the centre to support the LCS. The leachates were conducted to $300 \mathrm{~L}$ polyethylene tanks. The sub-base of each road unit had a different composition. The first was composed entirely of WBA and was considered the reference. The second and third roads contained $100 \%$ granular material.

Leachates Collection System (LCS) When analysing leaching data, the liquid-to-solid (L/S) ratio is a key parameter, since it allows leaching data from different tests to be compared. For this purpose, a roof structure was placed over the three road sites to avoid interference with rainwater. A water distribution system (Fig. 2) formed by a network of hoses was placed on top of each road and uniformly distributed in parallel. The main hose was connected in series to the water supply system to form the LCS. The incoming water was measured using an electronic meter. The exact amount of water in contact with the granular material was recorded and the L/S throughout the duration of the test was determined. An irrigation schedule of 110 days was set for the duration of the test in accordance with the rainfall in the zone. Irrigation always took place in the mornings, with an average ambient temperature of around $20 \pm 10{ }^{\circ} \mathrm{C}$. In order to simulate real conditions such as drought periods, irrigation was stopped from day 50 to 70 . The leachates generated by the incoming water passed through the LCS and accumulated in the polyethylene tanks. These cumulative leachates were regularly taken from the top of the tank after proper mixing. Each leachate sample was characterized with respect to the release values of selected species using the same procedures followed at laboratory scale. 


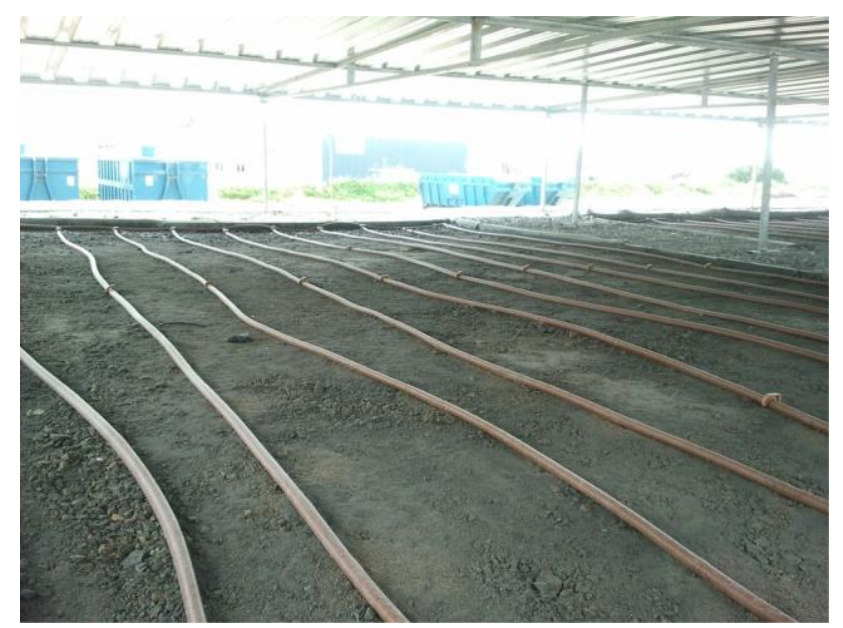

Fig. 2 Set of hoses forming the leaching collection system (LCS) of the three-roads pilot site

\section{Results and Discussion}

Chemical Composition of WBA, APC, Mortar, and Granular Material

The chemical composition results in terms of the most stable oxides determined by XRF for WBA, mortar, APC, and granular material are presented in Table 3. As shown, the major compounds in WBA are $\mathrm{SiO}_{2}$ and $\mathrm{CaO}$, most of which relate to the packaging glass and ceramics content of MSW [13]. These materials are barely affected by the incineration process and therefore remain the main compounds of this residue. The $\mathrm{Fe}_{2} \mathrm{O}_{3}$ and $\mathrm{Al}_{2} \mathrm{O}_{3}$ content is also significant; the former is related to the presence of unrecovered ferrous metals while latter may be a consequence of non-ferrous metals and ceramics such as clays [14]. Unlike WBA, the $\mathrm{SiO}_{2}$ content was very low in APC residues, which was mainly composed of lime $(\mathrm{CaO})$, the main compound used as alkaline absorbent during flue gas scrubbing from combustion. There was also very significant $\mathrm{Cl}^{-}$content from polyvinyl chloride (PVC) burning, and its leaching causes great concern for the landfill treatment of APC residues [15]. Due to its stabilization with PC, the chemical composition of mortar was very similar to that of APC residues, with the added contribution of $\mathrm{PC}$ in terms of $\mathrm{SiO}_{2}$ content. Likewise the composition granular material was quite similar to that of WBA (which makes up $80 \%$ of its total content), with the additional amounts of lime from APC residues (10\%). With respect to crystal mineralogy, the XRD patterns obtained (not shown) showed that amorphous $\mathrm{SiO}_{2}$ and $\mathrm{CaCO}_{3}$ were the main components of WBA and granular material. As for mortar, taking into account that the hydrated phases of PC are chiefly amorphous, the predominant phases were halite $(\mathrm{NaCl})$ and sylvite $(\mathrm{KCl})$ from APC.
Table 3 Chemical composition of WBA, mortar (M), APC, and granular material $(\mathrm{GM})$ determined by means of XRF

\begin{tabular}{lllll}
\cline { 2 - 5 } Oxides & WBA $(\%)$ & $\mathrm{M}(\%)$ & APC $(\%)$ & GM $(\%)$ \\
\hline $\mathrm{SiO}_{2}$ & 43.3 & 21.7 & 6.64 & 39.15 \\
$\mathrm{CaO}$ & 16.9 & 45.3 & 48.35 & 26.59 \\
$\mathrm{Cl}$ & 0.14 & 9.08 & 8.855 & 0.89 \\
$\mathrm{Fe}_{2} \mathrm{O}_{3}$ & 14.1 & 1.65 & 0.79 & 16.89 \\
$\mathrm{Na}_{2} \mathrm{O}$ & 7.58 & 4.44 & 4.28 & 3.71 \\
$\mathrm{Al}_{2} \mathrm{O}_{3}$ & 5.80 & 3.82 & 4.02 & 4.87 \\
$\mathrm{MgO}$ & 2.22 & 1.87 & 1.73 & 2.02 \\
$\mathrm{~K}_{2} \mathrm{O}$ & 1.11 & 2.10 & 4.33 & 1.67 \\
$\mathrm{CuO}$ & 0.23 & - & - & 0.13 \\
$\mathrm{SO}$ & 0.65 & 4.53 & 6.24 & 1.53 \\
$\mathrm{TiO}_{2}$ & 0.35 & 0.68 & 0.86 & 0.3 \\
$\mathrm{P}_{2} \mathrm{O}_{5}$ & 1.97 & 0.51 & 1.36 & 1.1 \\
$\mathrm{ZnO}$ & 0.18 & 0.31 & 0.72 & 0.19 \\
$\mathrm{PbO}$ & - & 0.13 & 0.12 & 0.03 \\
\cline { 2 - 5 } & & & &
\end{tabular}

Mechanical Properties of WBA/APC/PC Mixtures

The results of compressive strength (MPa) versus content (wt\%) of APC residues are shown in Fig. 3. To facilitate understanding, five curves were distinguished by $\mathrm{PC}$ content $(20,10$, and $8 \%)$ with and without the admixture. As it can be seen in all cases, the compressive strength values decreased dramatically as the APC content increased. This decrease is related, among others, to the increasing amount of water needed as the cement is replaced by APC. The mixture corresponding to $20 \mathrm{wt} \%$ of $\mathrm{PC}$ shows a maximum value at $5 \mathrm{wt} \%$ of APC, reaching nearly $18 \mathrm{MPa}$. From this point, the compressive strength showed a linear decay when APC increased. This maximum is mainly due to pozzolanic effect of APF on the amorphous phases of WBA. In this regards some authors have replaced PC by

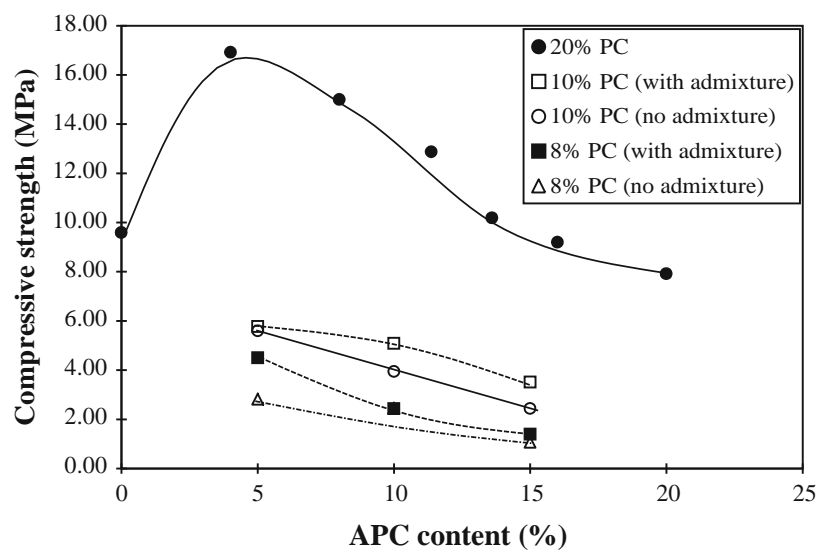

Fig. 3 Compressive strength values (MPa) as a function of APC content (wt \%) for WBA/APC/PC mixtures 
Table 4 Leaching concentration values $\left(\mathrm{mg} \mathrm{kg}^{-1}\right)$ of selected species according to EN 12457-4 for WBA, WBA/ $\mathrm{APC} / \mathrm{PC}$ formulations, and APC

\begin{tabular}{|c|c|c|c|c|c|c|c|c|}
\hline & \multirow[t]{2}{*}{ WBA } & \multicolumn{2}{|c|}{ WBA/APC/PC } & \multirow[t]{2}{*}{ APC } & \multicolumn{3}{|c|}{ Landfill legislation $^{a}$} & \multirow[t]{2}{*}{ Revalorization $^{\mathrm{b}}$} \\
\hline & & $8 \% \mathrm{PC}$ & $10 \% \mathrm{PC}$ & & Inert & Non-hazardous & Hazardous & \\
\hline As & 0.210 & 0.001 & 0.001 & $\backslash 0.520$ & 0.5 & 2 & 25 & 1 \\
\hline $\mathrm{Ba}$ & 0.390 & 12.895 & 15.044 & 39.300 & 20 & 100 & 300 & \\
\hline $\mathrm{Cd}$ & $\backslash 0.01$ & 0.030 & 0.026 & $\backslash 0.020$ & 0.04 & 1 & 5 & 1 \\
\hline $\mathrm{Cr}$ & 0.33 & 0.057 & 0.050 & $\backslash 0.040$ & 0.5 & 10 & 70 & 5 \\
\hline $\mathrm{Cu}$ & 3.462 & 1.497 & 0.938 & 0.790 & 2 & 50 & 100 & 20 \\
\hline $\mathrm{Hg}$ & $\backslash 0.01$ & 0.040 & 0.040 & $\backslash 0.040$ & 0.01 & 0.2 & 2 & 0.2 \\
\hline Mo & 0.774 & 0.227 & 0.117 & 2.520 & 0.5 & 10 & 30 & \\
\hline $\mathrm{Ni}$ & 0.055 & 0.115 & 0.170 & $\backslash 1.320$ & 0.5 & 10 & 30 & 5 \\
\hline $\mathrm{Pb}$ & 0.012 & 1.996 & 2.139 & 47.350 & 0.06 & 0.7 & 5 & 5 \\
\hline $\mathrm{Sb}$ & 0.830 & 0.114 & 0.079 & $\backslash 0.040$ & 0.1 & 0.5 & 7 & \\
\hline $\mathrm{Se}$ & 0.208 & $\backslash$ D.L. & $\backslash$ D.L. & 2.820 & 4 & 50 & 200 & \\
\hline $\mathrm{Zn}$ & $\backslash 0.2$ & 1.052 & 1.008 & 19.830 & 0.5 & 2 & 25 & 20 \\
\hline
\end{tabular}

Catalan landfill legislation: DOGC 5370 del 30 de Abril de 2009

Catalan legislation for residues revalorization: DOGC 2181 del 13 de Mayo de 1996. Maximum values allowed

${ }^{\mathrm{a}}$ Values for landfill classification

${ }^{\mathrm{b}}$ Maximum values allowed for revalorization
APC due to its binder properties. However, the use of a high percentage of APC in a concrete formulation implies a high W/PC ratio, which reduce compressive strength [16-18]. A significant decrease $(* 75 \%)$ in the mechanical properties was observed when the PC content was reduced to $10 \%$ : from 7.9-16.9 to 3.5-5.8 MPa using an admixture. When the admixture was not added, the compressive strength values decreased further, especially for specimens containing $8 \mathrm{wt} \%$ of PC. A higher Pc contents entail an increase in the final price of the material and therefore might compromise large-scale viability. The most suitable formulation was therefore 10/10 (APC/PC wt $\%$ ) with the addition of MIRA 43 admixture (hereinafter known as $80 / 10 / 10$ due to its WBA/APC/PC content), since this showed good results. Abrasion resistance was evaluated for the mixtures that contained an appropriate level of PC from an economical point of view (10\%) and with admixture, since this enhanced the mechanical properties. The average Los Angeles coefficients obtained for the 80/10/10 and WBA were 43 and $35 \%$ respectively. The former is significantly higher than the minimum value for road construction materials in Spain, according to the Spanish Technical Specifications for Road Construction (PG3, 2010), which sets a minimum value of $35 \%$ [19]. The noncompliance of $80 / 10 / 10$ with the PG3 was attributed to the reduction in compressive strength due to the substitution of PC for APC residues, which led to fragmentation under compaction conditions. Moreover, it seems that some of the APC residues remained and covered the WBA particle surface, thus hindering the bond with PC and increasing the quantity of fines. A strategy to overcome these shortcomings was to develop a mortar containing APC/PC, as explained in "APC/Portland Cement Mortar" section. Different proportions of APC/PC were taken into consideration (see Table 2), and the selection criterion focused on obtaining the best environmental properties, given that this is the main concern when it comes to APC recycling ("Leaching of WBA, WBA/APC/PC Mixtures and Mortar at Laboratory Scale" section).

Leaching of WBA, WBA/APC/PC Mixtures and Mortar at Laboratory Scale

The release values $\left(\mathrm{mg} \mathrm{kg}^{-1}\right)$ for selected species (as regulated by the Catalan legislation on landfill classification and revalorization) for WBA, WBA/APC/PC formulations ( 8 and $10 \%$ of PC with admixture), and APC residues using the batch leaching test (EN-12457-4) are shown in Table 4. As it can be seen, heavy metals leaching from WBA was below the threshold established by both the landfill classification legislation and revalorization legislation, and was classified as non-hazardous and inert in the case of the former. The two WBA/APC/PC mixtures considered had release values below the limit established for revalorization, as a consequence of the pozzolanic effect of PC, which showed a greater effect in $10 \%$ PC formulations (lower leaching values). The heavy metals and metalloids values remained within the range established for both residues. It was possible to attribute much of the $\mathrm{Ba}$, $\mathrm{Cd}, \mathrm{Ni}, \mathrm{Pb}$ and $\mathrm{Zn}$ leaching to APC residues, while $\mathrm{Sb}$ and 
Table 5 Leaching concentration values $\left(\mathrm{mg} \mathrm{kg}^{21}\right.$ ) of selected species according to EN 12457-4 for the different mortar formulations PC

\begin{tabular}{|c|c|c|c|c|c|c|c|c|c|c|c|c|c|}
\hline \multirow[t]{2}{*}{$(\%)$} & \multirow[t]{2}{*}{$\operatorname{APC}(\%)$} & \multicolumn{12}{|c|}{$\left(\mathrm{mg} \mathrm{kg}^{-1}\right)$} \\
\hline & & As & $\mathrm{Ba}$ & $\mathrm{Cd}$ & $\mathrm{Cr}$ total & $\mathrm{Cu}$ & $\mathrm{Hg}$ & Mo & $\mathrm{Ni}$ & $\mathrm{Pb}$ & $\mathrm{Sb}$ & $\mathrm{Se}$ & $\mathrm{Zn}$ \\
\hline 70.00 & 30.00 & $\backslash 0.100$ & 20.632 & $\backslash 0.020$ & $\backslash 0.200$ & $\backslash 0.400$ & $\backslash 0.040$ & 0.559 & 0.310 & 0.791 & $\backslash 0.040$ & $\backslash 0.040$ & 0.617 \\
\hline 60.00 & 40.00 & $\backslash 0.100$ & 32.304 & $\backslash 0.020$ & $\backslash 0.200$ & $\backslash 0.400$ & $\backslash 0.040$ & 0.513 & 0.340 & 1.128 & $\backslash 0.040$ & $\backslash 0.040$ & $\backslash 0.100$ \\
\hline 50.00 & 50.00 & $\backslash 0.100$ & 29.648 & $\backslash 0.020$ & $\backslash 0.200$ & $\backslash 0.400$ & $\backslash 0.040$ & 0.533 & 0.360 & 1.028 & $\backslash 0.040$ & $\backslash 0.040$ & 0.285 \\
\hline 40.00 & 60.00 & $\backslash 0.100$ & 42.868 & $\backslash 0.020$ & $\backslash 0.200$ & $\backslash 0.400$ & $\backslash 0.040$ & 0.516 & 0.420 & 1.009 & $\backslash 0.040$ & $\backslash 0.040$ & 0.332 \\
\hline 30.00 & 70.00 & $\backslash 0.100$ & 78.374 & 0.023 & $\backslash 0.200$ & $\backslash 0.400$ & $\backslash 0.040$ & 0.711 & 0.540 & 2.764 & 0.116 & $\backslash 0.040$ & 1.859 \\
\hline
\end{tabular}

$\mathrm{Cu}$ leaching were caused by WBA. There was significant leaching of $\mathrm{Pb}$ and $\mathrm{Zn}$ from $\mathrm{APC}$ residues; values were above the revalorization and non-hazardous classification limits. In this regard, the encapsulation effect of $\mathrm{PC}$ over $\mathrm{APC}$ in the WBA/APC/PC formulation was very effective. Thus, increasing the PC content showed improved environmental behaviour, as shown in Table 5 for the different mortar formulations. The $\mathrm{pH}$ and conductivity $(\mathrm{k})$ values remained in the same range (12.9-13.3 and $11.7-15.5 \mathrm{mS}$ $\mathrm{cm}^{-1}$, respectively). As the $\mathrm{APC}$ residues content in the mortar increased, the release concentration of $\mathrm{Zn}, \mathrm{Pb}, \mathrm{Ni}$, $\mathrm{Mo}, \mathrm{Ba}$, and $\mathrm{Sb}$ increased, with maximum leaching values at $70 \%$ of APC. All the values obtained were below the limits set out in the revalorization legis- lation (see Table 4), so the criteria adopted for selecting the optimum mortar formulation was based on economic via- bility and its inert or non-hazardous residue classification, according to the Catalan landfill legislation (also included in Table 4). Thus, the mortar formulation with $50 \%$ of APC and $50 \%$ PC (50/50) complied with the economical requirements and the release values of $\mathrm{Cr}, \mathrm{Cu}, \mathrm{Hg}, \mathrm{Cd}, \mathrm{As}, \mathrm{Sb}, \mathrm{Se}$, and $\mathrm{Zn}$ were classified as inert, while $\mathrm{Mo}, \mathrm{Ni}$ and $\mathrm{Pb}$ were classified as non-hazardous. Therefore, a granular material (GM), as briefly defined in "Granular Material (GM) for the Pilot-Scale Roads" section, was prepared separately using $20 \%$ of the optimum mortar $(50 / 50 \%$ of APC/PC) before being mixed with $80 \%$ WBA. Hence, the 80/10/10 composition was maintained, although a different preparation method was used. The laboratory results of the mechanical and environmental performance of the granular material are presented in the next section, along with those obtained in the pilot-scale study.

\section{GM: Mechanical and Environmental Performance}

\section{Laboratory Scale}

The average abrasion resistance values obtained for granular material were in the $38 \pm 1.5 \%$ range, close to the Los Angeles coefficient obtained for WBA ("Mechanical Properties of WBA/APC/PC Mixtures"' section) and lower than the WBA/APC/PC mixtures. The strategy used to reduce the quantity of fines generated under compaction by preparing mortar prior mixing with WBA was therefore successful. The release values $\left(\mathrm{mg} \mathrm{kg}^{-1}\right)$ from the batch leaching test (EN-12457-4) for $\mathrm{As}, \mathrm{Ba}, \mathrm{Cd}, \mathrm{Cr}, \mathrm{Cu}, \mathrm{Hg}$, $\mathrm{Mo}, \mathrm{Ni}, \mathrm{Pb}, \mathrm{Sb}, \mathrm{Se}$, and $\mathrm{Zn}$ were below the limits set for inert classification (Catalan legislation, see Table 4). With respect to the column leaching experiments, these were performed in duplicate and the results are presented as the average. The cumulative L/S ratio of the column leaching test started at $0.01 \mathrm{~L} \mathrm{~kg}^{-1}$ and reached an average of $2 \mathrm{~L} \mathrm{~kg}^{-1}$ after $48 \mathrm{~h}$. The $\mathrm{pH}$ remained in the $11.8-12.4$ range for all experimental trials and the conductivity values remained steady at around $6 \mathrm{mS} \mathrm{cm} \mathrm{cm}^{-1}$. The release values $\left(\mathrm{mg} \mathrm{L}^{-1}\right)$ for chlorides and sulphates as a function of $\mathrm{L} / \mathrm{S}$ are presented in Fig. 4. As shown, the release of readily soluble $\mathrm{Cl}^{-}$from APC residues showed a wash-out peak typical of availability-controlled leaching [15, 20]. As for sulphates, their $\mathrm{pH}$-dependent release showed an initial increasing pattern before stabilizing at 4000-5000 $\mathrm{mg} \mathrm{L}^{-1}$ $[21,22]$. Whit respect to heavy metals and metalloids, the leaching of selected species (those included in the Catalan legislation: $\mathrm{As}, \mathrm{Cu}, \mathrm{Cr}, \mathrm{Ni}, \mathrm{Pb}$, and $\mathrm{Zn}$ ) as a function of $\mathrm{L} / \mathrm{S}$ is presented in Fig. 5. The concentration values $\left(\mathrm{mg} \mathrm{kg}^{-1}\right)$ of $\mathrm{Hg}$ and $\mathrm{Cd}$ were below the detection limit in all eluates analysed $\left(\bigwedge 0.01 \mathrm{mg} \mathrm{kg}^{-1}\right)$ and therefore not included in the graph. In order to facilitate interpretation, the left y-axis of Fig. 5 corresponds to $\mathrm{Ni}, \mathrm{Cr}, \mathrm{Cu}$, and $\mathrm{Pb}$ while the right $\mathrm{y}$-axis shows the values obtained for As and $\mathrm{Zn}$. As shown, the concentration values for all these species increased as the L/S ratio increased, although they tended to stabilise slightly after $\mathrm{L} / \mathrm{S} 1.5 \mathrm{~L} \mathrm{~kg}^{-1}$. Their immobilisation is mainly attributed to the pozzolanic reactions promoted by PC [23]. The next section contains a more thorough analysis of the behaviour of heavy metals and their immobilisation mechanism.

\section{Pilot Scale}

The granular material results at pilot scale are expressed as the average of roads number two and three (i.e. $100 \%$ of granular material as sub-base). The values obtained for the road site containing $100 \%$ WBA were used as a reference, 


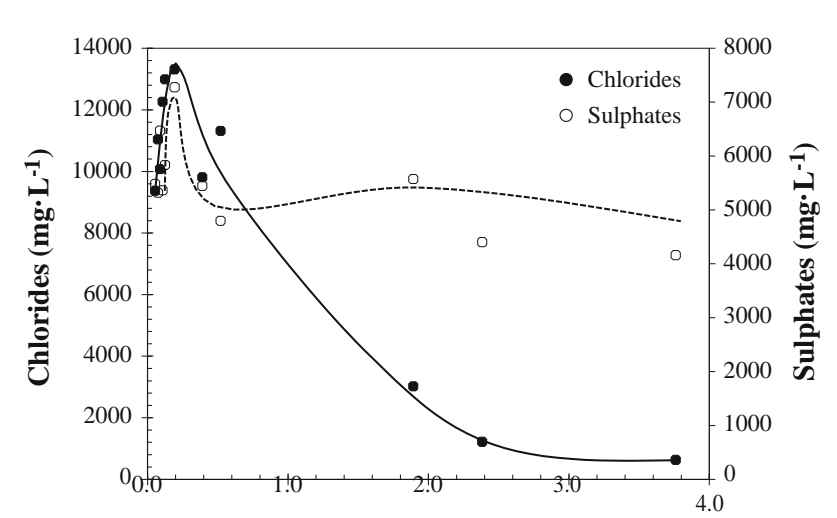

Liquid-to-solid ratio $\left(\mathbf{L} \cdot \mathrm{kg}^{-1}\right)$

Fig. 4 Cumulative leaching of chlorides (black circle) and sulphates (white circle) in $\mathrm{mg} \mathrm{L}^{-1}$ as a function of $\mathrm{L} / \mathrm{S}\left(\mathrm{L} \mathrm{kg}^{-1}\right)$ from granular material at laboratory scale (column percolation test)

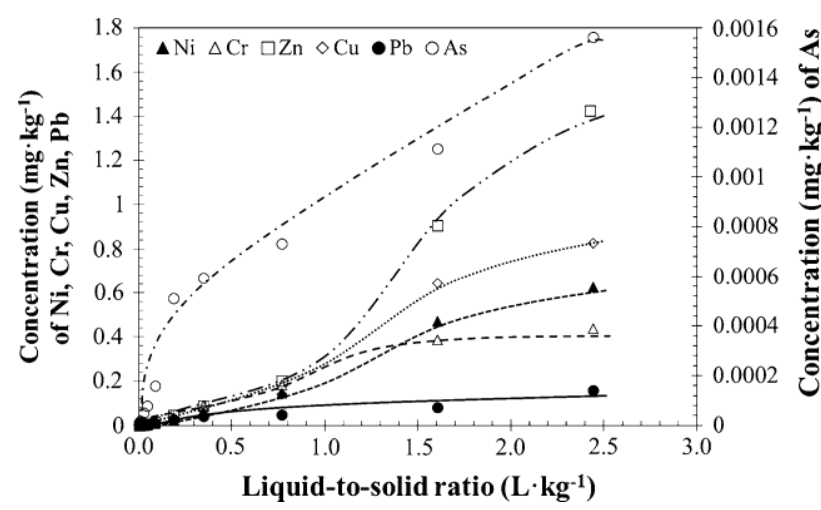

Fig. 5 Cumulative concentration release $\left(\mathrm{mg} \mathrm{kg}^{-1}\right)$ of selected heavy metals from granular material at laboratory scale (column percolation test)

to evaluate the effect of APC residues on environmental performance. The final $\mathrm{L} / \mathrm{S}$ value achieved in the field was close to $0.1 \mathrm{~L} \mathrm{~kg}^{-1}$ after 4 months. The $\mathrm{pH}$ remained in the 8-9 range throughout the whole experiment for the three test roads (100\% WBA and the average for GM). These values differed from those obtained at laboratory scale; this could be attributed to the temperature difference and atmospheric $\mathrm{CO}_{2}$ uptake that might have taken place in the open air $[24,25]$. With respect to conductivity, the granular material road sites values fluctuated in the $20-40 \mathrm{mS} \mathrm{cm}^{-1}$ range, which could be a consequence of the residence time and preferential flow pathways [24]. The leaching of chlorides and sulphates versus L/S is shown in Fig. 6. As in the laboratory, the release of chlorides showed a wash-out peak, and the difference between laboratory and field values can be attributed to the contact time between percolation water and solid material for the same L/S ratio [22]. Unlike the column experiments, the steady values under $2000 \mathrm{mg} \mathrm{L}^{-1}$ obtained for sulphates might have been a

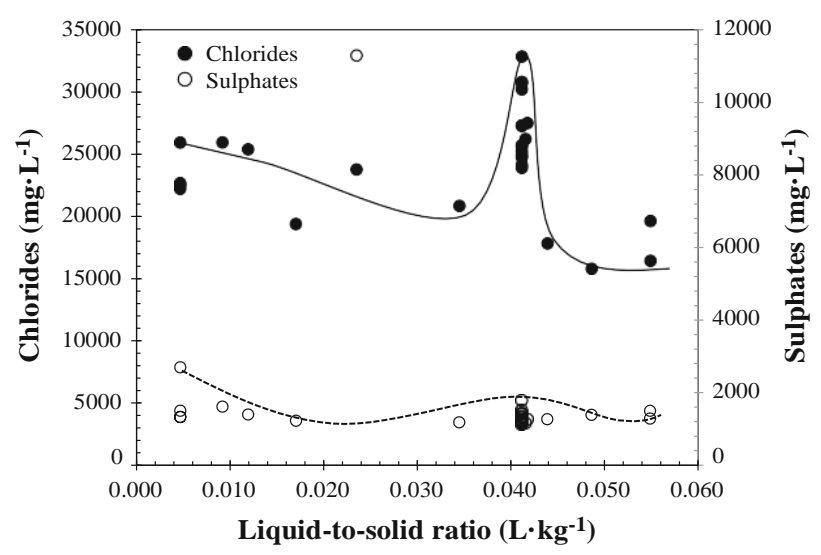

Fig. 6 Leaching of chlorides (black circle) and sulphates (white circle $)$ in $\mathrm{mg} \mathrm{L}^{-1}$ as a function of $\mathrm{L} / \mathrm{S}\left(\mathrm{L} \mathrm{kg}^{-1}\right)$ at field scale

consequence of the carbonation of calcium and WBA ageing, which could have favoured the formation of mineral phases such as ettringite and gypsum [26].

The data from the column leaching experiments (Fig. 5) and the field (Fig. 6) can be compared by representing the release values as a function of $\mathrm{L} / \mathrm{S}[27,28]$. The average release values of $\mathrm{As}, \mathrm{Cr}, \mathrm{Ni}$, and $\mathrm{Cu}$ are shown in Fig. 7, while the leaching of $\mathrm{Pb}$ is shown in Fig. 8. The comparison with WBA (not shown) showed that the metals content cannot be attributed solely to APC residues. Other than $\mathrm{Cu}$, the release values of all selected species at pilot scale were lower than those predicted by the column leaching test. These overestimations might be due to the potential mechanisms by which water enters the road body: an initial dissolution of species by the inlet water and a subsequent diffusion mechanism through the road layers [29]. Both driving forces may be affected by the preferential flows of inlet water as well as by water runoff, edge effects and lateral inputs, thereby reducing the disparity between the laboratory and field $[20,30]$. The sharp release at an L/S of $0.04 \mathrm{~L} \mathrm{~kg}^{-1}$ shown in Figs. 7, 8 is due to the drought periods simulation, which led to a sharp increase in values as a result of the reduction in water volume $(\mathrm{L})$ involved in leaching. It can be inferred from these two figures that the decrease in the release values of all species after the concentration peak might lead to a stabilization plateau. This is also supported by the fact that the $\mathrm{pH}$ range of the experimental test was that of minimum solubility for the majority of heavy metals and metalloids and is expected to decrease over time due to the effect of atmospheric carbonation and oxidation [31].

The immobilisation mechanisms of the selected species can be explained as follows. Although the concentration of arsenic was below the legislation limits, its release might be enhanced by the $\mathrm{Cl}^{-}$ions from APC residues and their initial wash-out effect [32]. Once the chlorides are washed- 

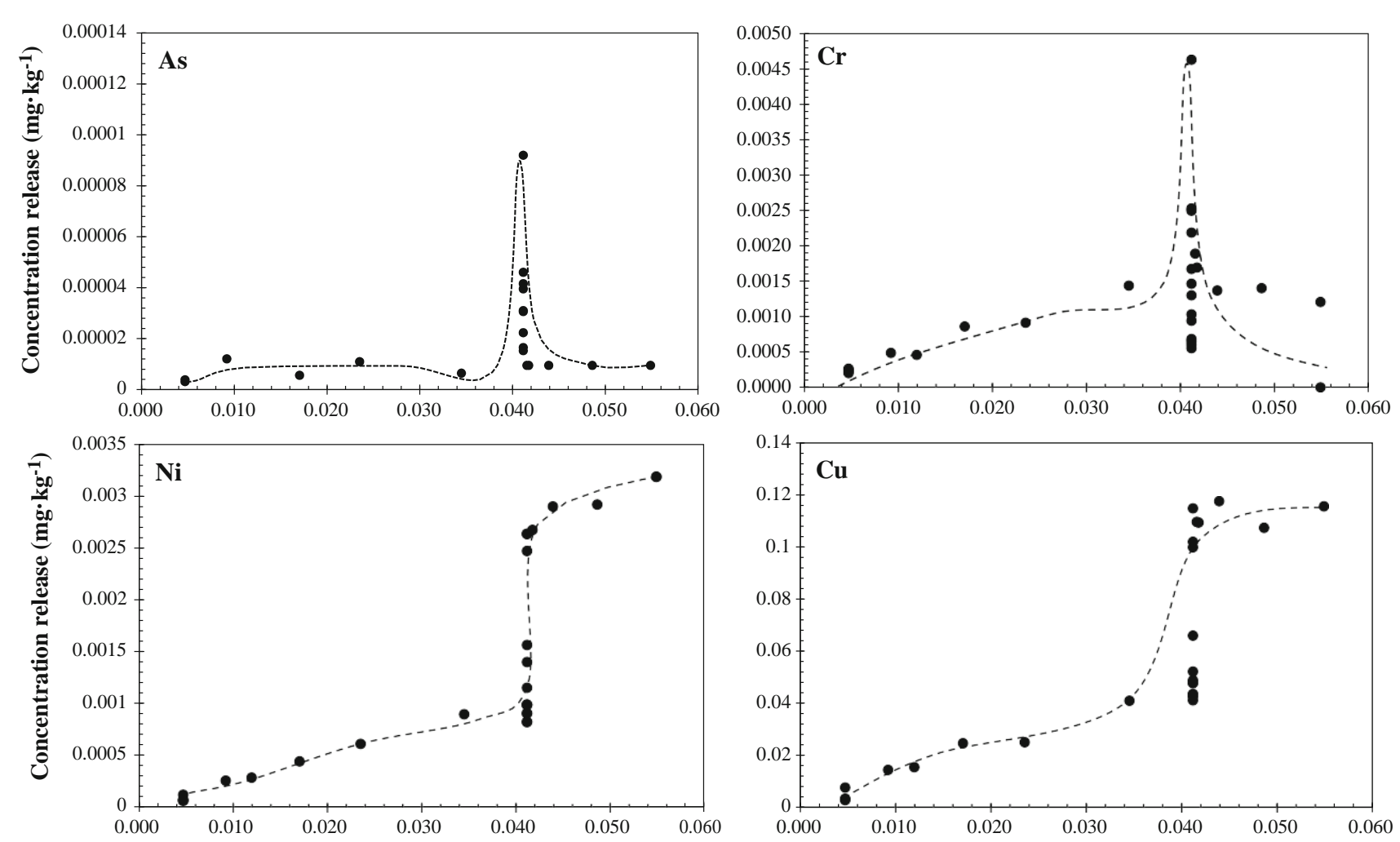

Fig. 7 Cumulative concentration release $\left(\mathrm{mg} \mathrm{kg}^{-1}\right)$ of $\mathrm{As}, \mathrm{Cr}, \mathrm{Ni}$, and $\mathrm{Cu}$ from granular material at field

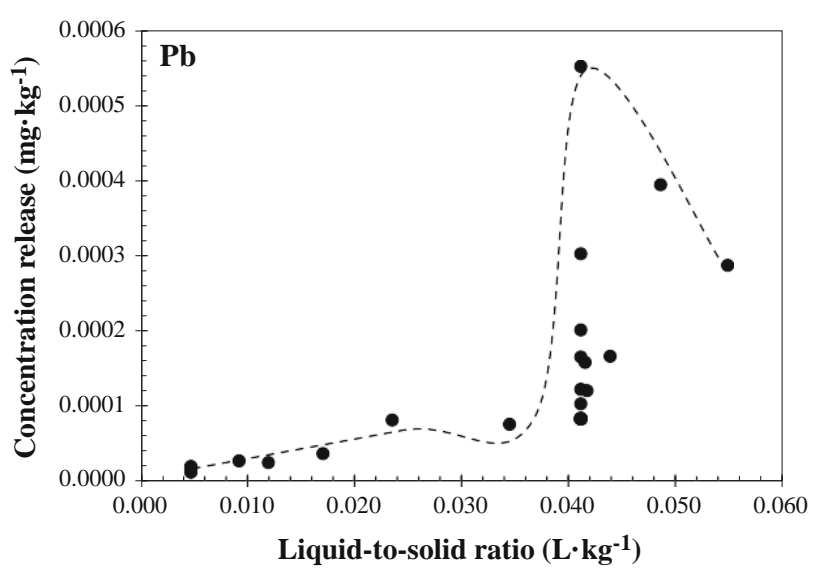

Fig. 8 Cumulative concentration release $\left(\mathrm{mg} \mathrm{kg}^{-1}\right)$ of $\mathrm{Pb}$ from granular material at field

out, the adsorption of arsenates over Fe (hydr)oxide surfaces might have been the main stabilisation mechanism [31, 33]. The concentration of $\mathrm{Cr}$ in the states of oxidation available $(\mathrm{Cr}(\mathrm{III})$ and $\mathrm{Cr}(\mathrm{VI}))$ is strongly influenced by $\mathrm{pH}$. In alkaline conditions the oxidation of $\mathrm{Cr}$ (III) to the more mobile $\mathrm{Cr}(\mathrm{VI})$ is favoured and high redox potential values are required [15, 34]. The $\mathrm{pH}$ conditions imposed at the granular material road sites led to $\mathrm{Cr}$ immobilisation. Like $\mathrm{Cr}$, nickel is also $\mathrm{pH}$-dependent and its release is mainly attributed to the low solubility of $\mathrm{Ni}(\mathrm{OH})_{2}$ in the test $\mathrm{pH}$, which is reported to be the main equilibrium controlling phase [33]. The significant leaching of $\mathrm{Cu}$ (mainly from WBA) could have been enhanced by long-term exposure under atmospheric conditions. $\mathrm{Cu}$ leaching is thought to be promoted by the oxidation of organic matter, which tends to form soluble compounds [10, 31, 35]. Its subsequent immobilization can be attributed to the formation of a less soluble copper (hydr)oxide or its sorption into amorphous Fe/Al-(hydr)oxides [31, 33]. The solubility of $\mathrm{Pb}$ (Fig. 8) is highest at $\mathrm{pH}$ values over 11 and the abovementioned $\mathrm{pH}$ range means its immobilisation over time is guaranteed. [30]. Therefore, the use of granular material containing APC residues as a sub-base material is an environmentallysafe recycling option.

\section{Conclusions}

The research carried out over a 10 year period to develop an environmentally safe method for recycling air pollution control (APC) residues was presented. The initial studies focused on formulating WBA/APC/PC mixtures to be used as a sub-base material in road constructions. In order to improve mechanical performance, a granular material was prepared by mixing crushed mortar (50\% APC residues and $50 \%$ of PC) with $80 \%$ WBA. The performance of this material was 
evaluated at laboratory and pilot scale. The results obtained in the laboratory using batch and column leaching tests showed the suitability of granular material as a safe-recycling option for APC residues. This was corroborated at three-roads site by assessing the potential leaching of heavy metals, metalloids, chlorides and sulphates for 4 months with artificial irrigation. The results showed that the immobilisation of all heavy metals and metalloids from APC is achieved by the pozzolanic effect of cement mortar. Therefore, according to Catalan legislation for waste revalorization, the use of granular material containing APC residues as a sub-base material, in the proportions proposed in this research (80\% WBA, $10 \%$ APC residues and $10 \%$ PC) and following the method explained in this article, is an environmentally-safe option for APC recycling.

Acknowledgments The authors would like to thank the SIRUSA and VECSA companies for their financial support and for providing access to sampling sites. Dr. Ricardo del Valle Zermeño is grateful to the Government of Catalonia for the research grant (FI-DGR 2014). The authors would like to thank the Catalan Government for the quality accreditation given to their research group DIOPMA (2014 SGR 1543). Dr. Jessica Giro-Paloma appreciate the financial support to Fundació Agustí Pedro i Pons for the granted fellowship. Thanks are also given to Mrs. Judit Gómez for the assistance with chemical analysis and data management.

\section{References}

1. "Packaging waste statistics"—-statistics explained (2014/2/3). http://epp.eurostat.ec.europa.eu/statistics_explained/index.php/ Packaging_waste_statistics

2. Fischer, C., Gentil, E., Koziel, L., Lindblad, B., Rispo, A., Sora, M.J., Ventosa, I.P., Ferraris, M., Nicolli, F., Paleari, S., Zoboli, R.: The importance of regional and local policies on municipal solid waste management in Europe - exemplified by six regions in Italy, Poland and Spain, Copenhagen (2014)

3. Chimenos, J.M., Fernández, A.I., Cervantes, A., Miralles, L., Fernández, M.A., Espiell, F.: Optimizing the APC residue washing process to minimize the release of chloride and heavy metals. Waste Manag. 25, 686-693 (2005)

4. Polettini, A., Pomi, R., Sirini, P., Testa, F.: Properties of Portland cement-stabilised MSWI fly ashes. J. Hazard. Mater. 88, $123-$ 138 (2001)

5. del Valle-Zermeño, R., Formosa, J., Chimenos, J.M., Martínez, M., Fernández, A.I.: Aggregate material formulated with MSWI bottom ash and APC fly ash for use as secondary building material. Waste Manag. 33, 621-627 (2013)

6. Schreurs, J.P.G.M., van der Sloot, H.A., Hendriks, C.: Verification of laboratory-field leaching behavior of coal fly ash and MSWI bottom ash as a road base material. Waste Manag. 20, 193-201 (2000)

7. Flyhammar, P., Bendz, D.: Leaching of different elements from subbase layers of alternative aggregates in pavement constructions. J. Hazard. Mater. 137, 603-611 (2006)

8. Lidelöw, S., Lagerkvist, A.: Evaluation of leachate emissions from crushed rock and municipal solid waste incineration bottom ash used in road construction. Waste Manag. 27, 1356-1365 (2007)
9. Bendz, D., Flyhammar, P., Hartlén, J., Elert, M.: Leaching from residues used in road constructions - a system analysis. In: Kassim, T.A., Williamson, K.J. (eds.) Water Pollution: Environmental Impact Assessment of Recycled Wastes on Surface and Ground. The Handbook of Environmental Chemistry, pp. 293-320. Springer, Berlin (2005)

10. De Windt, L., Dabo, D., Lidelöw, S., Badreddine, R., Lagerkvist, A.: MSWI bottom ash used as basement at two pilot-scale roads: comparison of leachate chemistry and reactive transport modeling. Waste Manag. 31, 267-280 (2011)

11. UNE-EN 83313:90: Concrete tests. Determination of the Consistency of Fresh Concrete. Slump Method. (1990)

12. Chandler, A.J.: Municipal solid waste incinerator residues studies in environmental sciences. http://www.scopus.com/inward/ record.url?eid=2-s2.0-84925379351\&partnerID=tZOtx3y1

13. Chimenos, J., Segarra, M., Fernández, M., Espiell, F.: Characterization of the bottom ash in municipal solid waste incinerator. J. Hazard. Mater. 64, 211-222 (1999)

14. del Valle-Zermeño, R., Giró-Paloma, J., Formosa, J., C.J.: Glass content in MSWI bottom ash: effectiveness assessment of recycling over time. In: Prof. Ing. Raffaello Cossu (ed.) Second Symposium on Urban Mining. Eurowaste Srl, Bergamo, Italy (2014)

15. Sabbas, T., Polettini, A., Pomi, R., Astrup, T., Hjelmar, O., Mostbauer, P., Cappai, G., Magel, G., Salhofer, S., Speiser, C., Heuss-Assbichler, S., Klein, R., Lechner, P.: Management of municipal solid waste incineration residues. Waste Manag. 23, 61-88 (2003)

16. Saikia, N., Kato, S., Kojima, T.: Production of cement clinkers from municipal solid waste incineration (MSWI) fly ash. Waste Manag. 27, 1178-1189 (2007)

17. Cabrera, M., Agrela, F., Ayuso, J., Galvin, A.P., Rosales, J.: Feasible use of biomass bottom ash in the manufacture of cement treated recycled materials. Mater. Struct. 49, 3227-3238 (2016)

18. Al-Rawas, A.A., Wahid Hago, A., Taha, R., Al-Kharousi, K.: Use of incinerator ash as a replacement for cement and sand in cement mortars. Build. Environ. 40, 1261-1266(2005)

19. Spanish general technical specifications for road construction (PG3). Ministry of Development Government of Spain., Madrid, Spain (2010)

20. Kosson, D.S., van der Sloot, H.A., Eighmy, T.T.: An approach for estimation of contaminant release during utilization and disposal of municipal waste combustion residues. J. Hazard. Mater. 47, 43-75 (1996)

21. Piantone, P., Bodénan, F., Chatelet-Snidaro, L.: Mineralogical study of secondary mineral phases from weathered MSWI bottom ash: implications for the modelling and trapping of heavy metals. Appl. Geochem. 19, 1891-1904 (2004)

22. Quina, M.J., Bordado, J.C.M., Quinta-Ferreira, R.M.: The influence of $\mathrm{pH}$ on the leaching behaviour of inorganic components from municipal solid waste APC residues. Waste Manag. 29, 2483-2493 (2009)

23. Todorovic, J., Svensson, M., Herrmann, I., Ecke, H.: Artificial carbonation for controlling the mobility of critical elements in bottom ash. J. Mater. Cycles Waste Manag. 8, 145-153 (2006)

24. Dabo, D., Badreddine, R., De Windt, L., Drouadaine, I.: Ten-year chemical evolution of leachate and municipal solid waste incineration bottom ash used in a test road site. J. Hazard. Mater. 172, 904-913 (2009)

25. Izquierdo, M., Querol, X., Josa, A., Vazquez, E., López-Soler, A.: Comparison between laboratory and field leachability of MSWI bottom ash as a road material. Sci. Total Environ. 389, 10-19 (2008)

26. López Meza, S., Kalbe, U., Berger, W., Simon, F.G.: Effect of contact time on the release of contaminants from granular waste 
materials during column leaching experiments. Waste Manag. 30, 565-571 (2010)

27. Grathwohl, P., Susset, B.: Comparison of percolation to batch and sequential leaching tests: theory and data. Waste Manag. 29, 2681-2688 (2009)

28. Quina, M.J., Bordado, J.C.M., Quinta-Ferreira, R.M.: Chemical stabilization of air pollution control residues from municipal solid waste incineration. J. Hazard. Mater. 179, 382-392 (2010)

29. Konrad, J.-M., Roy, M.: Mechanisms controlling seasonal variation of moisture content in roads. http://www.scopus.com/ inward/record.url?eid=2-s2.0-0002715906\&partnerID=tZOtx3y1

30. Apul, D.S., Gardner, K.H., Eighmy, T.T.: Modeling hydrology and reactive transport in roads: the effect of cracks, the edge, and contaminant properties. Waste Manag. 27, 1465-1475 (2007)

31. Meima, J.A., Comans, R.N.J.: The leaching of trace elements from municipal solid waste incinerator bottom ash at different stages of weathering. Appl. Geochem. 14, 159-171 (1999)
32. Olsson, S., Gustafsson, J.P., Kleja, D.B., Bendz, D., Persson, I.: Metal leaching from MSWI bottom ash as affected by salt or dissolved organic matter. Waste Manag. 29, 506-512 (2009)

33. Quina, M.J., Bordado, J.C.M., Quinta-Ferreira, R.M.: Percolation and batch leaching tests to assess release of inorganic pollutants from municipal solid waste incinerator residues. Waste Manag. 31, 236-245 (2011)

34. Rinehart, T.L., Schulze, D.G., Bricka, R.M., Bajt, S., Blatchley III, E.R.: Chromium leaching versus oxidation state for a contaminated solidified/stabilized soil. J. Hazard. Mater. 52, 213-221 (1997)

35. Johnson, C.A., Kersten, M., Ziegler, F., Moor, H.C.: Leaching behaviour and solubility-controlling solid phases of heavy metals in municipal solid waste incinerator ash. Waste Manag. 16, 129-134(1996) 